\title{
The Wearing OUT COMPENSATION OF Diesel ENGINES COMBUSTION CHAMBERS
}

\author{
Ostoia, D.; NegOitescu, A. \& TOKAR, A.
}

Abstract: This paper presents a method for wearing out compensation in diesel engines combustion chambers through mechatronics systems implementation. The connection between geometrical combustion diesel engine parameters which also shape the level of wear and the engine parameters can be realized by the Electronic Central Unit (ECU). The Electronic Central Unit can correlate the existent changes by realizing the connection between combustion chamber pressure and geometrical changes due to wearing out and command the engine actuators with the newer values that describe the diesel engine working conditions.

Key words: wear, engine, pressure, mechatronic, pollution
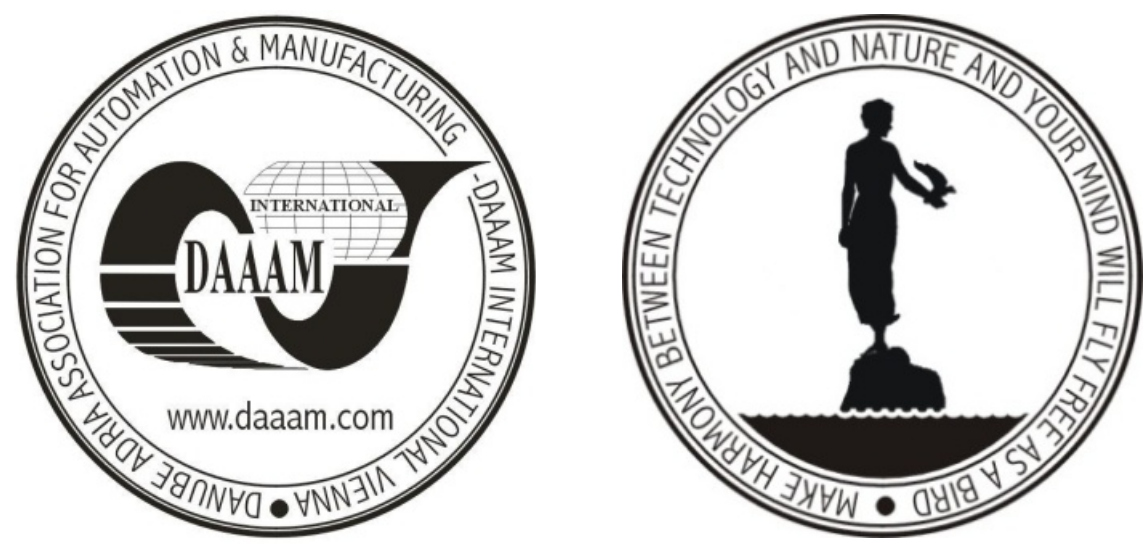

Authors' data: Lect.Dr.Ing. Ostoia, D[aniel]; Lect.Dr.Ing. Negoitescu, A[rina]; Dr.Ing., Tokar A[driana], Politehnica University of Timisoara, Mihai Viteazu Blv. 1, 300222, Romania, dostoia@yahoo.com, arina.negoitescu@yahoo.com, adriana_tokar@yahoo.com

This Publication has to be referred as: Ostoia, D[aniel]; Negoitescu, A[rina] \& Tokar A[driana] (2009). The Wearing Out Compensation of Diesel Engines Combustion Chambers, Chapter 16 in DAAAM International Scientific Book 2009, pp. 143-150, B. Katalinic (Ed.), Published by DAAAM International, ISBN 978-3901509-69-8, ISSN 1726-9687, Vienna, Austria

DOI: $10.2507 /$ daaam.scibook.2009.16 